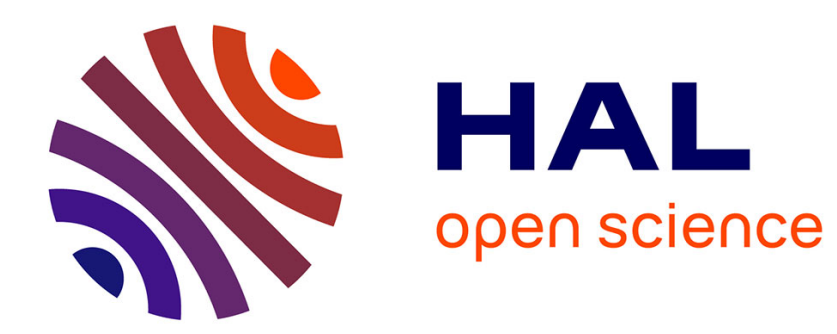

\title{
Immigrants, Banlieues, and Dangerous Things: Ideology as an Aesthetic Affair
}

Mustafa Dikeç

\section{To cite this version:}

Mustafa Dikeç. Immigrants, Banlieues, and Dangerous Things: Ideology as an Aesthetic Affair. Antipode, 2013, 10.1111/j.1467-8330.2012.00999.x . hal-01274405

\section{HAL Id: hal-01274405 \\ https://hal-enpc.archives-ouvertes.fr/hal-01274405}

Submitted on 15 Feb 2016

HAL is a multi-disciplinary open access archive for the deposit and dissemination of scientific research documents, whether they are published or not. The documents may come from teaching and research institutions in France or abroad, or from public or private research centers.
L'archive ouverte pluridisciplinaire HAL, est destinée au dépôt et à la diffusion de documents scientifiques de niveau recherche, publiés ou non, émanant des établissements d'enseignement et de recherche français ou étrangers, des laboratoires publics ou privés. 


\title{
Immigrants, Banlieues, and Dangerous Things: Ideology as an Aesthetic Affair
}

\author{
Mustafa Dikeç \\ Department of Geography, Royal Holloway, University of London, Egham, UK; \\ m.dikec@rhul.ac.uk
}

\begin{abstract}
This paper engages with the notion of ideology, bringing together Laclau's theorisation of the specificity of the ideological, and Rancière's notion of aesthetic regimes. Ideology, I argue, works through what it makes available to the senses and what it makes to make sense. It is in this sense that it is an aesthetic affair. This argument is illustrated with an account of the so-called "securitarian ideology" in France that characterises the repressive policies of the recent governments.
\end{abstract}

Keywords: aesthetics, ideology, banlieue, security, Laclau, Rancière

\section{The One and the Many}

One is alright. It is when there are many of them that there are problems (Brice Hortefeux, Former French Minister of the Interior, 6 September 2009).

In a rather tragic scene, a party member introduces Hortefeux to a young militant of Arab origin, explaining that he is "like them": he "eats pork and drinks alcohol". The minister is surprised: "Ah! That's not it at all, he doesn't fit the prototype at all!" Then he adds: "There always has to be one. One is alright. It is when there are many of them that there are problems." ${ }^{11}$ But should we be surprised? Various government members over the past years, including Presidents of the Republic, have publicly made similar statements. Even so, it was a milestone for a minister condemned for a racial insult to continue to remain in office. Arguably such statements have been influential in the consolidation of the "prototypes" Hortefeux was referring to.

My title is inspired by George Lakoff's 1987 book, Women, Fire, and Dangerous Things. Lakoff chose this intriguing title to expose the workings of the standard chain of inference: from conjunction to categorisation to commonality. His title, in turn, was inspired by Dyirbal, an Australian aboriginal language, which includes women, fire, and dangerous things in the same category-but not because, as the usual view of categorisation suggests, they have common properties. Women and fire are in this same category not because they are both considered dangerous things, but because they fall into one of the four categories that are used to classify the objects of the Dyirbal universe. This category, balan, also includes some fishes, most birds, scorpions and crickets, things connected with water or fire, sun, stars, shields, some spears and some trees-a categorisation as seemingly surreal to the Western 
mind as Borges' taxonomy of the animal kingdom found in an ancient Chinese encyclopaedia.

Nevertheless, the standard chain of inference based on common properties is a part of our everyday categorisations. In this paper, I will focus on the "common"on what is made "common" so that conjunctions, categorisations, and eventually "prototypes", may follow. Inspired by the French case, I will argue for an aesthetic approach to ideology, building on the works of Ernesto Laclau and Jacques Rancière. Ideology, I will argue, may be seen as the consolidation of an aesthetic regime that puts in place-in common-"sensible evidences" that suggest certain chains of inference while disallowing other associations, and present a certain situation as the naturally given one. This is not, however, to suggest that all parts of the population are equally summoned by a given aesthetic regime or to deny that there are multiple domains of sensible evidences. My aim is to reconsider ideology as world-making through an examination of the so-called "securitarian ideology" of the recent French governments.

In fact, there are all sorts of reasons for staying away from "ideology". One of these involves the notion's many contested meanings. As Giddens once wrote, "[i]f there were a prize for the most contested concept, the concept of ideology would very nearly rank first" (Giddens 1983; cited in Susser 1996:1). ${ }^{2}$ There is, as Susser wrote, a "definitional turmoil that surrounds the term", which makes it not only contested but elusive as well. The term is also tainted, with connotations ranging from distortion to fanaticism. "Not surprisingly ideology turns out to refer to ideas of which one disapproves" (Susser 1996:2). It would not be an exaggeration to suggest that ideology is a political kiss of death; an accusation of being ideological, as Panagia (2006:2) put it in reference to the 1970s and 1980s-the high point of the "end of ideology" thesis_- "is tantamount to a personal insult, immediately challenging one's moral rectitude".

So there we have it. Contested, elusive, tainted ... not to mention the theoretical difficulties surrounding the concept. There are, it seems, two main difficulties with the concept of ideology, both of which were largely responsible for its abandonment. One of these concerns the epistemological problem of truth versus falsity, or as Laclau (1996:17) puts it, "the denial of the possibility of a metalinguistic vantage point which allows the unmasking of ideological distortion". This, in a sense, is the loss of a hitherto assumed "neutral" (ie extra-ideological) viewpoint from which to reveal truth or expose ideology's distortion. One requirement for a "working theory of ideology" as defined by Frow (1994:295) is "that it not assert a relationship of truth to falsity (and so its own mastery over error) but concern rather the production and the conditions of production of categories and entities within the field of discourse". This is what Slavoj Žižek (1994:7) calls the "representationalist" problematic:

[I]deology has nothing to do with "illusion", with a mistaken, distorted representation of its social content. To put it succinctly: a political standpoint can be quite accurate ("true") as to its objective content, yet thoroughly ideological; and, vice versa, the idea that a political standpoint gives of its social content can prove totally wrong, yet there is absolutely nothing "ideological" about it. 
The other difficulty is of an inflationary nature. Simply put, the imperialistic expansion of the concept of ideology has stripped it of any analytical value, leading to its abandonment as a meaningful category of analysis. As Žižek (1994:16) puts it, ideology "somehow grows 'too strong', it begins to embrace everything, inclusive of the very neutral, extra-ideological ground supposed to provide the standard by means of which one can measure ideological distortion". In other words, the notion of ideology has become too capacious for its own (analytical) good.

Arguably, these difficulties were influential in the relative abandonment of the concept of ideology, which both Žižek (1994) and Eagleton (1991) attribute to the rise of postmodernism and poststructuralism. This had to do, as Eagleton (1991:xi-xii) explains, with "a rejection of the notion of representation", a growing "epistemological scepticism", and "a reformulation of the relations between rationality, interests and power" which made the concept of ideology look redundant. However, I believe both of the difficulties identified above can be addressed with a conception of ideology that first, eschews truth/falsity claims, and second, involves a definition of the specificity of the ideological in order to avoid ending up with a notion that means everything but nothing in particular. My reconsideration of the notion owes to the re-appearance of the term, in the last few years, in French government discourse and policies around the theme of security.

\section{The "Securitarian Ideology"}

Despite variations, the last four governments in France, in particular the three that were formed after the 2002 elections marking the coming of the Right to power, have been characterised by their commitment to a so-called "securitarian ideology" ("idéologie sécuritaire") - a term commonly used in the media and critical scholarship to refer mainly to the increased powers and repressive practices of the police (Autain et al 2006; Bourgouin 2008; Chalom and Léonard 2003; Les dossiers du Canard 2009; Rajsfus 2002; Rigouste 2009). And this ideology has a very precise spatial referent: "la banlieue" (in the singular), a shorthand term to denote the darker inhabitants of social housing neighbourhoods in the peripheral areas of cities. But what does it mean to talk about a "securitarian ideology" rather than, say, a securitarian strategy, orientation or policy? And how do we go about learning what this ideology is (provided it is one)? My paper takes this epistemological question as a point of entry to reconsider the notion of ideology in aesthetic terms.

It seems to me that there are two ways of approaching this question. To learn about this "ideology", one may enumerate, explain and analyse the measures, policies and practices associated with it. But in my view this approach does not go very far in terms of telling us what is specifically ideological about all this; it merely tells us about its manifestations. The other way, which I find more promising, involves looking at the conditions of possibility for such manifestations. In other words, it involves not just looking at measures, policies and practices, but at the consolidation of a regime that has made their deployment possible, which also involves looking at the creation of the very objects that are now targeted by these. This second 
approach allows us to relate the epistemological question to a conceptual one on the notion of ideology, which, I will argue, can be conceived in aesthetic terms. This aesthetic approach also seems more sensible to the question of silences, of what is not or cannot be articulated in a given discursive regime, although this is not an issue I explore in this paper. ${ }^{3}$

Here lies, in my view, the political and theoretical import of revisiting the notion of ideology. The so-called "securitarian ideology" goes much deeper than the mere import of security measures from across the Atlantic (or the Channel, for that matter). It first and foremost organises the "givens" of the situation. Qualifying post-2002 government policies as ideology (as it is usually done) carries with it the implication that faced with the same situation, another government would have adopted different policies and strategies (presumably "better" ones, oriented perhaps more towards prevention than repression). The problem with this kind of usage of the term is that it presents ideology as a strategy to be adopted to deal with a given situation, rather than understanding the "situation" itself as the terrain of ideology. It thereby obscures the contingency of the givens of the situation that make the application of such measures conceivable, possible, legitimate, even "necessary" in the first place. This is a problem that needs to be addressed because reducing ideology to strategy, application or an ensemble of measures feeds the misleading "end of ideology" theses in their various forms, which themselves are, as Žižek (1994) argues, ideological claims par excellence. I am inclined to follow Laclau in his suggestion that "we will continue living in an ideological universe" (1996:19), a statement I embrace not for its predictive value but for its political significance, as implying the undesirability and impossibility of total closure, which, in fact, the end of ideology thesis implies. Here we have one significant political reason to keep the notion of ideology and practice of ideological critique alive: a commitment to a non-essentialist order, constantly in the making within a field of forces, and never lending itself to total closure that the end of ideology implies. Critique of ideology is important to avoid transforming the contingent into the absolute or the naturally given. Taken-for-grantedness is precisely how ideologies establish themselves, making their effects felt as necessary responses to a given situation. Therefore, despite all is shortcomings, the critique of ideology is effective in pointing to the symbolic constitutions of the social: a word of caution, as it were, against blind commitment to the reality of the real, a call to question-if not suspect-the facticity of facts.

Ideology, I would like to argue, is about the very (re-)configuration that presents a certain situation as the naturally given one. I am proposing here a re-engagement with the notion of ideology in aesthetic terms. This should be seen as an attempt to bring together the discursive and aesthetic dimensions through an engagement with Laclau's theorisation of ideology and Rancière's sustained emphasis on the relationship between aesthetics, politics and orders of governance. In a sense, I complement Laclau's theory organised around a "dialectics of incarnation/deformation" by bringing in an aesthetic dimension that, in my view, is essential to making this dialectics work, allowing it to be sensible, hence operational. This aesthetic dimension involves what Rancière calls a "partition of the sensible" or "distribution of sensible evidences", which refers to "the way in 
which the abstract and arbitrary forms of symbolisation of hierarchy are embodied as perceptive givens" (Rancière 2003:7).

\section{Laclau and the Specificity of the Ideological}

The originality of Laclau's theorisation of ideology is that he does not dismiss the idea of distortion (or illusion)-usually among the first casualties in critiques of the notion of ideology-but gives it another twist. The distortion involved in an ideological process, according to Laclau, does not necessarily operate to deform truth into falsity, reality into illusion, consciousness into false consciousness. Rather, the source of distortion is the "illusion of closure"; that is, a commitment to the possibility of social positivity and objectivity with neither lack nor excess, nor unrepresentable elements.

Why can the notion of distortion not be abandoned? Historically, the weak aspect of this critique of ideology was not the idea of distortion as such, but rather the postulate of an extra-ideological level from which a critique of ideology could be launched. Indeed, the existence of such a vantage point (extra-ideological, extradiscursive, metalinguistic, etc) was necessary for any critique of ideology at all. Once such a privileged point is nullified, the critique of ideology, Laclau points out, could only be intra-ideological, which greatly undermines the analytic and critical purchase of the notion. But this does not amount to negating the idea of distortion as such; rather, what Laclau does is to redefine what constitutes the distortion. The ideological distortion or illusion no longer consists of the contents of what is seen (or uncovered) from an extra-ideological level, but of the very commitment to the existence of such a level. As Laclau (1996:3) puts it, "what now constitutes a distorted representation is the very notion of an extra-discursive closure". The focus of critique now is the symbolic partitioning of the social and knowledge about it, to use Rancière's terms. There is, therefore, a shift of focus from contents to the organisation and distribution of the sensible.

This may be illustrated by reconsidering Althusser's theory of ideology (even though he did not subscribe to the idea of distortion as illusion or false consciousness). Althusser famously conceived of ideology and science as opposites, where the latter would become the privileged terrain from which the critique of ideology would proceed. ${ }^{4}$ Critiques of Althusser have usually (and rightly in my view) questioned the capacity of science to play the role of this neutral, disinterested, unaffected agent of critique (is not science itself replete with various ideologies after all?). However, what constitutes ideology is not the opposite of science but the very partitioning Althusser's theory postulates:

Ideology is not in fact a collection of discourses or a system of ideas ... The dominant ideology is not the shadowy Other of the pure light of Science; it is the very space in which scientific knowledges are inscribed, and in which they are articulated as elements of a social formation's knowledge. It is in the forms of the dominant ideology that a scientific theory becomes an object of knowledge (Rancière 1994:152-153, emphasis added). ${ }^{5}$

Let us go back to the idea of distortion. Laclau's innovation is that he makes it constitutive of the ideological moment. A form of "constitutive distortion" now becomes key to any ideological operation, which involves a "double movement": 
the incarnation and deformation of particular objects or contents, or what Laclau calls a "dialectics of incarnation/deformation". The ideological instance for Laclau is that moment when a particular content (an economic measure, a new security policy, etc) starts to incarnate something that is more and different than itself (as in "This new security policy is the first step towards the restoration of the Republic's authority and values"). What is incarnated is an impossible object- "the fullness of community" - that depends on the particular content in question. In other words, it is the postulated "possibility of constituting the community as a coherent whole" (Laclau 1996:6) that distinguishes ideology from, say, a system of ideas.

In the French context, there was an identifiable period where "la banlieue" —in the singular-started to fulfil that incarnating function. Of course the banlieues of French cities are much more diverse than the singular term deceptively suggests, but over the years "the banlieue" has become a shorthand term to denote certain groups of the population (and problems seen to be associated with them) who live in peripheral social housing estates. When the "menace" of banlieues was first articulated in the 1970s, ${ }^{6}$ it did not involve "ethnic" or religious connotations. But starting with the 1980s, and particularly the early 1990s, Islam and the "problem of immigration", the problem being the "integration" of non-European immigrants and their descendants into French society, became dominant themes. With the development of a republican nationalism in the 1990s, "the banlieue" has started to fulfil, though negatively, its incarnating role as a space seen as incompatible with the integrity of the Republic. In political and media discourses the problem of banlieues implies a threat to the values of the Republic, French identity and the authority of the state. This image of the banlieues, now commonplace in the mainstream, was not merely the product of lazy journalistic accounts; it was constituted by the state's various practices of articulation-policies, official discourses, reports, statistics, and mappings - that predate the post-2000 governments. These practices contributed to the consolidation of an image of banlieues as aberrations in an otherwise (allegedly) cohesive society, threatening its peace and identity as unwelcome intruders from beyond the city gates, and turned them into the "badlands of the republic" (Dikeç 2007) against which the republic's "values" were defined. Thus, the "barbarians at the gates" have become the constitutive outside, similar to what Constantine Cavafy's evoked in his 1904 poem "Waiting for the barbarians":

Why this sudden unrest and confusion?

(How solemn their faces have become.)

Why are the streets and squares clearing quickly, and all return to their homes, so deep in thought?

Because night is here but the barbarians have not come.

Some people arrived from the frontiers,

and they said that there are no longer any barbarians.

And now what shall become of us without any barbarians?

Those people were a kind of solution.

In Laclau's terms, this would be illustrative of an ideological distortion projecting onto a particular object (in this case, la banlieue) the incarnate possibility of constituting the community as a coherent whole (in this case, a Republic with a single identity and shared values). Or, to put it differently, the particular object in 
question becomes a means of representation to project the fullness and coherence of community (which, in this case, is seen as being under threat by that object). It is emblematic in this sense that Jean-Louis Borloo, soon after taking office as Minister of State for the City in the 2002 Raffarin government, explained his plan for the designated urban policy neighbourhoods (which involved the renovation of the social housing estates in the banlieues) as the "new battle of France" (Le Monde 28 May 2002). What this suggests is that we cannot consider ideology apart from the practices that construct particular objects or contents.

Laclau thus defines the ideological moment as consisting of a transformation such that a particular object starts to incarnate something more and different from itself. But we are still left with the question of how such a transformation-or "constitutive distortion" - occurs. Or, as Laclau himself asks, "how the operation of distortion becomes visible" (1996:6; emphasis added). Laclau's answer here is "deformation", which involves "making a certain content equivalent to a set of other contents" ( $p$ 6). In other words, incarnation proceeds by establishing relations of equivalence between particular objects through acts of articulation (see, for example, Laclau and Mouffe 1985). "Deformation" is meant to capture the processes whereby particular elements, objects, or contents within an imagined totality are articulated such that their differences from each other become subsumed within a "chain of equivalence" formed through these articulations. Under a logic of equivalence each element can be substituted for one another and also play the role of incarnation. An example here would be terms such as "banlieue" and "youth", which are commonly used in political and media discourses to evoke issues ranging from immigration to insecurity, from ethnic separatism to Islamic fundamentalism and even terrorism.

This, in my view, is a correct but incomplete diagnosis as it tells us what the deformation does without really telling how it does it. For a particular element to incarnate something more and different from itself by establishing a set of equivalences, it has to be placed in a regime of references that lend themselves to common perception though not necessarily leading to shared interpretations. But they need to be made available to the senses. This is where the aesthetic dimension enters. Drawing from Rancière's writings on the relationship between aesthetics and politics, I argue that a notion of "aesthetic regime" (or a "regime of sensibility") can fill this gap in Laclau's notion of ideology. The question of what is made available to the senses when making judgements is a politically significant one, and it is one of the main theoretical contributions of an aesthetic approach to the notion of ideology. As Panagia (2006:94) maintains, a "political position or action may be attractive not only because it makes moral sense but also because what allows it to make sense is a spectator's appraisal", that is to say, judgment. Therefore, my reconsideration of the notion of ideology draws on Laclau's theorisation to define the specificity of the ideological, but brings in a focus on aesthetics and sense experience, which are inextricably linked to judgment and the making of political identities (Dikeç 2012; Ferguson 2007).

\section{Rancière's Aesthetic Regimes}

Rancière (2000b) defines an aesthetic regime as the articulation of three elements: modes of production of objects (of what is made available to the senses); their forms 
of visibility, though a better term here would perhaps be "sensibility" (how they are made available to the senses); and forms of conceptualising and problematising them (how they are talked and thought about), which, in turn, supports the conditions of possibility of the first two. An aesthetic regime combines modes of production with "forms of visibility and enunciative possibilities. It is a system of relations between doing, seeing, saying and sensing" (Rancière 2000b:19). Therefore, analyses of aesthetic regimes, thus defined, need to focus on three components: practices (what is made available to the senses); visibility (how is it made available to the senses); and conceptualisation (how is it made to make sense).

With this definition of an aesthetic regime in mind, I argue that ideology may be seen as an aesthetic regime that fulfils two conditions: incarnation and deformation, as defined by Laclau. Or, better yet, ideology is an aesthetic regime that makes the dialectics of incarnation/deformation sensible and operational. It consists of the reconfiguration of a perceptive field by putting in place sensible evidences, which has material effects on ways of being, saying, and doing. It is not merely the collection of discourses or systems of ideas; it is the configuration of the "very space", as Rancière put it, in which certain discourses and ideas are inscribed and articulated, certain objects are given to sensory experience, and made to make sense. This is, in many ways, Foucault with an aesthetic twist.

But what does Rancière mean by "very space"? This, I think, is related to his notion of the partition of the sensible, a sensible (and governmental) order that depends on certain framings of times and spaces (for example, setting of working times, delimitation of spaces, defining one's place, etc). What is important here is that this order works through the sensible evidences that are put in place, which constitute a universe of sensible experience. Žižek's remarks are helpful here:

when a racist Englishman says "There are too many Pakistanis on our streets!", howfrom what place-does he "see" this-that is, how is his symbolic space structured so that he can perceive the fact of a Pakistani strolling along a London street as a disturbing surplus? That is to say, here one must bear in mind Lacan's motto that nothing is lacking in the real: every perception of a lack or a surplus ("not enough of this", "too much of that") always involves a symbolic universe (Žižek 1994:11).

Rancière's debt, however, is to Foucault: "The idea of the partition of the sensible is no doubt my own way of translating and appropriating for my own account the genealogical thought of Foucault-his way of systemizing how things can be visible, utterable, and capable of being thought" (Rancière 2000d:13). Rancière is not trying to argue that the consolidation of such orders lead to illusionary perceptions, while reality lies somewhere else. His point is that such orders work through what they present to the senses as self-evident facts; he is concerned about the worlds of sensible experience that such orders create, rather than the falsity or reality or what is presented to the senses. "What is ultimately important for me", he writes, "is to dismiss the facile opposition between a plane of appearances and a plane of reality and to show ... how it is that the "social" - a category supposedly intended to explain away and thereby refute the "ideological" —is in fact constituted by a series of discursive acts and reconfigurations of a perceptive field (2000a:117; emphasis added). 
It is in this sense that ideology is an aesthetic affair, aesthetics understood not as a theory of art or beauty, but as the framing of what is (made) available to the senses, going back, therefore, to what was implied by the Greek aisthesis; namely, sensory experience, sensation or perception by the senses. Such framings condition perceptions of lack and surplus ("too many immigrants", "not enough repression"), and in doing so, they reconfigure the thresholds of toleration and perceptions of the "whole" and its "parts". Ideological configuration of a perceptive field plays on sensibilities and may easily reify an identified lack or surplus as an object of fear and threat in the social imaginary, as the French case illustrates. It is remarkable, for example, that "the banlieue" was listed among the "major phobias" of the French in the new millennium by the daily paper Libération (8 April 2002).

An aesthetic regime is a regime of sensibility. This means that we have more than mere sensory experience of phenomena; this sensible experience is also related to ways of rationalisation and conceptualisation so that it makes sense. "Sensibility to a phenomenon", Rancière (2007:9) writes, "is always linked to the modes of naming and rationalising it". This is what I try to capture with the term "sensible evidences": they are available to the senses and they make sense. Here the term evidence also needs to be understood in a double meaning as invoking a quality of obviousness and also a quality of providing a ground for judgment: it is evident and it is evidence. My argument, then, is that ideology works through what it makes available to the senses and what it makes to make sense. This is what I mean by ideology as an aesthetic affair. Once ideology is understood in this way, the focus of ideological critique becomes how sensory and sensible experiences are made common (which, of course, does not necessarily mean that everyone will interpret them in exactly the same way). It is highly emblematic in this sense that one of the first actions of Nicolas Sarkozy when he took office as Minister of the Interior in 2002 was to modify the periodicity of the publication of delinquency figures, and to make them publicly available more frequently (Le Monde 31 May 2002). The concrete measures that followed were only the "natural" answers of the government to a situation the givens of which it had redefined by designating police activity as an indicator of security in its attempt to "restore the Republican order". This so-called securitarian ideology, therefore, consists of the consolidation of an aesthetic regime, even if this involves, as we will see, the adoption of redundant or inapplicable penal laws, and the fabrication of statistics as it suits the government.

\section{The Facticity of Facts}

What, then, are the components of this aesthetic regime? What kinds of practices, forms of visibility and conceptualisation are involved? Let me start with conceptualisation first. This involves both legitimisation-of "the figures" (such as delinquency statistics) —and delegitimisation —of certain forms of protest, such as revolts by certain groups. The recurrent banlieue revolts have been accompanied by an official discourse that seeks to delegitimise such incidents, although similar manifestations of discontent by other groups are rendered legitimate. Here Sarkozy's speech to rioting Breton fishermen is exemplary: 
Fishermen don't cheat. When people here demonstrate, when they use violence, it's not to have fun, it's never to harm anybody, it's because they're desperate, because they no longer have any option, and they feel condemned to economic and social death (Sarkozy in Lorient, 3 April 2007).

This, of course, is quite different from calling the rioters "scum" or "hoodlum". As Begag had once observed regarding the peasant demonstrations:

But there are different types of violence. The young people of Vaulx-en-Velin who burn and ransack stores are "casseurs"7; farmers who destroy railway lines are "angry". This difference in political and media treatment may be justified by the fact that the first are not claiming anything definite and everything at the same time, while the second are most often fighting for the defense of their acquired rights (Begag 1990:114).

Banlieue revolts are thus reduced to acts of pointless violence committed by delinquents, but the revolts of the fishermen are elevated to legitimate manifestation of discontent by honest people. Banlieue revolts, in other words, do not make sense. ${ }^{8}$ This kind of delegitimisation obscures the complex geography of grievances by highlighting merely the acts of violence involved in revolts. It also, importantly, hides from view forms of violence that banlieue inhabitants disproportionately suffer from. One of these is mass unemployment: in the deprived social housing estates of banlieues, unemployment levels reach $25 \%$, and within the young population up to $40 \%$. These are mainly former working class neighbourhoods, hard hit by economic restructuring in the 1970s and 1980s, which have never quite recovered since.

This geography of mass unemployment also overlaps with a geography of discrimination. Such housing estates are marked by a strong territorial stigmatisation, which means that living there becomes a handicap (notably in job applications). Yet another form of violence that the state officials rarely, if ever, talk about, when referring to such areas, is police violence. Of the 48 large-scale banlieue revolts of the 1990s, 34 were provoked by the killing of a banlieue youth, and in 30 of those, the police was implicated (Dikeç 2007). Several other revolts in the 2000s followed this pattern, including the massive revolts of autumn 2005, Villiers-le-Bel in 2007, and Grenoble in 2010. Part of the youths' resentment stems from the apparent impunity of the police, with a perception of the police as being "above the law" (see Amnesty International 2009). For example, the policeman who killed a youth of North African origin in Mantes-la-Jolie in 1991 was only tried in 2001, which contradicted the government's stated commitment to "swift, firm and tough response" in the domain of justice (Tévanian 2003:114; see also Rajsfus 2002), and consolidated the already established perception of impunity (the case was eventually dismissed). The two policemen implicated in the death of two adolescents in Clichy-sous-Bois, which was the triggering incident for the 2005 revolts, also benefited from a similar decision 6 years after the incidents (Libération 27 April 2011). The five young people arrested after the 2007 Villiers-le-Bel revolts, however, were less lucky; they received a "swift, firm and tough response" -3-15 years in prison, announced in 2010, despite great concern about the lack of solid proof since the accusations were based on anonymous and paid denunciations, and statements by the captured youth made during their 4-day police custody (see, for 
example, Libération 21 June 2010, and the excerpts of the minutes Pierre Tévanian published on his website (http://Imsi.net/Les-mots-de-Pontoise).

With the effacement of these geographies of grievances, the revolts, unsurprisingly, do not make much sense to the French "public". By contrast, delinquency figures are made to make a lot of sense. Since 2002, the publication of delinquency figures has been made into a key moment in French politics and the media (Data 2009; Matelly and Mouhanna 2007). Following a visit to Rudy Giuliani in 2002, Sarkozy (then the Minister of the Interior) changed the publication frequency of the statistics compiled by the police, publishing them monthly, and no longer annually. This was a major tenet of his policy, as expressed in his speech to prefects (the state's local representative) the following year:

These results, I ask you to communicate them every month ... I know it is not always the case. Some believe that working on a press release or uploading on the intranet is enough. They are mistaken. You must talk to the press. You must also have your Departmental Directors of Public Security and commanders speak as often as possible. Media silence is a mistake (Sarkozy 2003).

Thus numbers-both delinquency figures and the number of new laws themed under "security" - have been turned into a powerful (and supposedly transparent) indicator of the activity, efficiency, and authority of the government, although there have been many commentaries that have argued the opposite (see, for example, Libération 22 April 2009). As the pseudonymous author Lorraine Data puts it:

In our media-influenced society, a message has to get through in twenty seconds, so it's necessary to risk saying simple things on highly complex issues, in a vocabulary that is not always accurate. In this context, a sort of dictatorship of the figure has taken over the TV and most people participating in the public debate (politicians, journalists, "experts" of varied qualifications) continue to believe or fake a belief that figures "speak for themselves". Whether they realise or not, they gradually teach the public to "fetishise" figures and make it an unavoidable reference point to "give credence" to information and messages delivered by TV presenters as well as by their politician guests. The figure, both peremptory and drab, therefore tends to become a substitute for arguments. The figure is simple and gives the feeling (or rather the illusion) that one knows and masters the issue at hand (Data 2009:6).

Figures are thus made to make sense. But how are they are fabricated and made available to the senses? Between 2002 and 2009, more than 60 proposed measures on security were voted on in the French parliament. In the same period, more than 30 laws on security, penal justice and immigration were adopted. Nicolas Sarkozy himself initiated 21 laws and 21 decrees on security between 2002 and 2007-a new law or a decree every 6 weeks. These laws, to take a few examples, generalised the use of Flash-Ball guns by the police; cancelled a previous law on the presumption of innocence; created new offences (such as gatherings at the halls of buildings, sexual soliciting, aggressive begging, insult to the flag and the national anthem, ambush) and increased sentences for existing ones; facilitated deportations; increased the detention of "illegal" immigrants from 12 to 32 days; gave new powers to the police for surveillance, infiltration, and access to private data; introduced measures to punish illegal downloads; increased police custody 
first to 4 days (for "organised crime"), then to 6 days (for "terrorism") and without a lawyer for 3 days; introduced the extremely vague notion of "organised gang"; suppressed the 10-year residency cards for immigrants; increased mayors' powers in the domain of policing; banned (by decree) the concealment of the face during demonstrations; made the suppression of family benefits possible in the case of school absenteeism; introduced severe punishments with an "anti-gang" law based not on facts but on a suspicion of intention to collectively commit violence; and banned full-face veils (burqa) ... the list goes on (see Les dossiers du Canard 2009 for a full list and explanations; see also Jean 2010).

These actions of the government are without precedent in the history of the republic, and it has been referred to as "penal populism" (Salas 2008), "punitive populism" (Ferret and Mouhanna 2005), "penal frenzy" (Danet 2008), "legislative inflation" (Jean 2010), and "legislative bustle" (Barella 2008). ${ }^{9}$ These laws generated abundant commentary and the government never missed an opportunity to advertise them. Such security-themed legislative reforms are indeed quite visible. Their effects, however, do not match up to their number. Dominique Barella, a judge, summarised, somewhat provocatively, the effects of the 21 laws (and 21 decrees) adopted between 2002 and 2007: "nothing". This, of course, is not meant to imply that these new laws have no material effects. Rather, Barella's point is that they hardly ever achieved the communicated objectives, such as a decrease in the number of crimes and offences. Although the successive governments never failed to exploit the visibility of such security and repression-themed legislative reforms, most of the time the new laws are either redundant or impossible to apply. As Jean (2010) observes, most of the penal texts voted since 2002 followed an accelerated procedure, with only one parliamentary reading, which limits discussion, deliberation, and eventually the quality of the law in question.

Most of these laws are characterised by one or two of the following three features: they are ineffective (ie not obtaining the desired or communicated results, though increasing police harassment, police custody, and incarceration), impossible to apply, or redundant. Take, for example, the law on gatherings in building halls, punishable with up to 2 months in prison and $€ 3750$ fine. Adopted in 2003 and aimed mainly at the banlieue youth, this law proved, as with many others, inapplicable, or, "practically impossible to prove" as Barella (2008) put it, although it did allow the police to round banlieue youth up and take them into police custody. Or take the so-called "anti-gang" law ("loi anti-bande") that was adopted in 2010. As the Collectif Liberté Egalité Justice put it in a communication, ${ }^{10}$ it is redundant because the penal code already allows severe punishment of collective infractions. It is also worryingly vague as it is based on a suspicion of intention to commit violence as a group. Consider finally another new law adopted in June 2010 that seeks to "systematically" suspend the family benefits in case of school absenteeism. This, again, is redundant since a similar measure has existed since schools became public in France in the nineteenth century. But as Mucchielli (2008) observes, since 2002 in particular the frenzy and multiplication of legal edicts has made law symbolic and declarative, and no longer reformative.

Frenzy and fabrication also characterise government statistics. The government's practice of manipulation and communication of statistics came to such a point 
that in 2009 a book, Le grand truquage (The Big Rigging), was published under the pseudonym of "Lorraine Data". The book brought together numerous civil servants (working in the state statistical institute or the ministries concerned, hence the anonymity), who specialise in statistics in different domains and were able to expose how the government uses and abuses statistics as it sees fit, from purchasing power to unemployment figures, from poverty to education, from immigration to delinquency. The chapter on delinquency argues that Sarkozy, when he became the Minister of the Interior, took control not only of the communication of delinquency figures but also of their production to make sure that they are always "good". What is referred to as "figures of delinquency" are in fact statistics from the police and the gendarmerie; that is, the number of incidents and instances of repressive activity (arrests, police custody, etc) recorded by the police and the gendarmerie, which then becomes an administrative means for evaluating their efficacy. But it goes further than that: the police and the gendarmerie are asked in advance to obtain certain figures. Sarkozy was very clear on this from the outset. As he told police chiefs in June 2002:"I want our action to translate into figures ... Every year, you should establish quantitative objectives of improved efficiency, of increased case-solving, of means distribution".

Mucchielli (2008b) argues that police statistics now serve two functions, one internal, the other external. Internally, it has become a means for administrative control. Sarkozy made it quite clear that the careers of prefects depended on their "numbers". Externally, it has become a means for political communication, a showcase for the actions of the government in the domain of "security" as defined by it. But this obsessive focus on figures has given rise to dubious practices. Thus, in April 2003 the journal Le Canard enchaîné published a copy of a letter sent by a police chief to his officers in Cannes, asking them to "boost the figures" because the statistics in his district were not good enough and would cause him administrative headache-indeed, his job. The journal Libération revealed another case in October 2003, citing a letter that was circulated by the public security director of the department of Hérault (in the Languedoc-Roussillon region). Worried about the numbers in his district, the director gave precise instructions to his officers: the anti-criminal brigade "must [emphasis in original] achieve the minimum objective of six police custodies per day"; the daily shift "minimum four police custodies per day" of which "minimum two at night"; only two for the dog brigade, and seven for the proximity police, not to forget at least one by the road team.

Since these incidents, although many administrators have been careful not to put their instructions down in writing, one of them did so, and a copy of this was recently published in Libération (5 January 2010). In this instance, the police chief in Lyon, seeing that the number of arrests in his district declined in November in relation to figures from the previous year, sent a note to his police officers in early December, asking them to do "their maximum" in order to "limit the decline in figures" and thus not to "suffer from the discontent and negative consequences from high command". In yet another case, in Châlons-en-Champagne this time, the police chief gave detailed instructions on the figures to be obtained, describing precisely how many people each unit should take in for questioning ("interpeller") 
per day over the year. While such stipulation in advance of the number of arrests to be made constitutes a violation of the penal procedure, to my knowledge no police chief or prefect has been punished for fixing such objectives. ${ }^{11}$

This numerical fabrication has introduced new practices for police officers on the ground as well. In the same issue of Libération cited above, Yannick Danio, the delegate of the major police union in France, gives some examples of these new practices. For example, the police are asked to arrest five joint smokers rather than a dealer, because five smokers count as five offences plus five cases solved, whereas a drug dealer would only count as one data point in the statistics, making the pursuit for joint smokers much more "worthwhile" —and easier-than arresting the drug dealer. Furthermore, the former group is all the more "profitable" because it does not require research and investigation. Indeed, this new "religion of numbers" (as Danio refers to it) has created whole new groups of "profitable targets" the police regularly uses to pad its statistics: joint smokers, knife carriers, prostitutes (for soliciting) and "illegal" immigrants. In Calais (a city north of France with a concentration of "illegal" immigrants hoping to cross the Channel), for example, it is a well established practice to take in "illegal" immigrants to police stations to feed the statistics, taking the same people in more than once, even those who are about to be removed from the country. While boosting numbers that show "positive" activity by the police, there is also a concurrent and widely established practice of discouraging citizens to file complaints in police stations so that the "bad" numbers do not go up.

Inevitably, there have been repercussions of this frenzy for the populations targeted. Amnesty International published a report in 2009 on police violence and the virtual impunity of the police in France, and created a special website dedicated to this issue. ${ }^{12}$ Even the Commission Nationale de Déontologie de la Sécurité (an independent administrative authority responsible for overseeing the practices of the police and others working in the domain of security) denounced police practices in its 2009 report. One effect is a remarkable increase in rates of incarceration, and since 2002 French prisons have been overpopulated (Aubusson de Cavarlay 2008; Milburn 2008). Figures on the number of people taken into police custody, which have become a measure of police activity and efficacy, increased by $137 \%$ in 8 years, going up from 337,000 in 2001 to 800,000 in 2009 (Le Monde 12 March 2010). This increase, however, did not necessarily translate into an increase in convictions. It is up to the police to decide to take a person into police custody, and the gap between the number of police custodial arrests and convictions suggests rushed and haphazard, rather than carefully considered, police practices in this domain. The increase in police custodies also exposed the limited resources of the police to deal with such a rise, and the dreadful conditions of police custody have become a major concern (Le Monde 12 March 2010). However, the numbers of police custodies are part of the statistics compiled by the police and communicated by the government as part of their activity to achieve "security".

These are, then, some of the components of the aesthetic regime that this securitarian ideology has consolidated over the years, making certain things available_-or common — to the senses, and making them make sense. Ideology is not simply about being committed to a certain view of the world. It is about actively 
constructing that "world" through such practices of putting sensible evidences in place.

\section{The Girl on the RER}

The idea of making things common to the senses brings to mind the notion of sensus communis. Indeed, we could argue that an aesthetic regime contributes to the formation of "common sense", the literal translation of the Latin term. The term is compatible with what I am proposing as long as it implies two things: the making common of sensory and sensible experiences and providing a basis for judgment. Therefore, I do not subscribe to an understanding of common sense as a given, shared "culture" that has an effect on everyday, spontaneous understandings of the world, though clearly there are links. Rather I espouse an understanding of sensus communis that combines two strands, one that treats it in terms of shared meaning and the other as a faculty of judgment (which, in the case of Kant, is restricted to aesthetic judgment). Schaeffer (2004:278) identifies three different meanings of sensus communis. The first is rhetorical and refers to "non-reflective judgments" such as shared assumptions, values, prejudices that an orator could rely upon when addressing an audience. The second is philosophical and refers to a faculty of the mind that "orders" sense impressions. The third is a composite of these two meanings, where sensus communis refers to a faculty of the mind that perceives "relations or connections between objects and sense perceptions or between individual cases or events". The key point here is that "sensus communis is the basis of practical judgment (phronesis)".

Hence the political import of an aesthetic approach: if sensus communis is postsensory, as suggested in these definitions, and also the basis of practical judgment, then there are important political reasons for paying attention to what is made available to the senses (and what is not). In his exploration of how political identities emerge through judgment, Ferguson (2007:1) argues that "[j]udgments are the basis of political identities"; while similar judgments may lead to political solidarity or at least affinity, dissimilar ones often lie at the source of antagonistic identities.

As Rancière himself acknowledges (2000c, 2007) we are getting close here to the Kantian notion of "a priori forms" that order our sensory perceptions. This may raise a few questions, so some clarification seems necessary. In his Critique of Pure Reason (1998 [1781]) Kant famously defined space and time as a priori forms of intuition or sensibility. As a priori forms of sensibility, space and time make objects possible and provide form to our sensory perceptions, and thus, to our experience of the world. According to Kant, we receive a multitude of sensations, but this multitude is somehow organised into a whole-this is space, as an a priori form of sensibility, providing a form for the objects presented to us, giving shape to our experience. To explain it differently, we encounter particular objects in experience, and become aware of them as spatially (and temporally) ordered - that is, as exhibiting relations of simultaneity and succession-and as having a form - that is, possessing spatial features such as shape and extension. According to Kant, this spatial (and temporal) system of relations is a priori and has its source in our minds; namely, our faculty of spatial intuition, or our "outer sense", as he also refers to it. That it is a priori means, 
however, that it is already given to us, built in our minds, that it does not rely on experience, but merely gives a form to our awareness of things in space (and time). This, I suspect, is where many geographers of a materialist persuasion would start to feel distinctly uneasy. Is spatial (or for that matter, temporal) form already given to us, imposing itself on our perceptions, ordering our experience of the world?

Rancière does not go that far. Time and space, for him, are "forms of configuration of our 'place' in society, forms of distribution of the common and the private, and of assignation to everybody of his or her own part" (2005a:13). Whereas Kant dealt with aesthetics as a priori forms that order what presents itself to sense experience, Rancière deals with it as a "partition of the sensible" (le partage du sensible): as the form of what is presented to the senses, and actualised in particular historical and geographical contexts. The word "partage" here is almost an oxymoron as it means both "partition" and "sharing". Rancière uses it to refer to as what is "put in common" [mis en commun] and shared in the community, but also to what is separated and excluded, such as the separation of the visible and the invisible, audible and inaudible, speech and noise, possible and impossible. Another meaning of the word "partage", as used in the phrase "en partage", is an inheritance, something one is given, or, better yet, endowed with (usually positive, such as talent). So another connotation of Rancière's "partage du sensible" would be to be given certain ways of perceiving and making sense of things. ${ }^{13}$

Therefore, Rancière both alters and expands the notion of a priori forms. This is the first major difference from a strictly Kantian interpretation. The second difference lies in the source of a priori forms; they are no longer in the mind-where Kant had them-but in particular historical (and geographical, we could usefully add) contexts as products of specific conjunctures, conflicts and tensions (2009:157). The partition of the sensible, therefore, is a contingent distribution of forms that structure common-though not consensual-experience and ways of thinking, marked by tension and conflict. "A partition of the sensible", writes Rancière, "is always a state of forces [état des forces]" (2009:158).

Understood in this way, the ideological function of an aesthetic regime would be something close to what Déotte (2004:81) refers to as the placing of "an interpretive grid over any event" in a non-totalitarian way. In other words, there is no claim that everyone will respond in the same way to a given event, though an event-even a non-event-may surprisingly expose the workings of an aesthetic regime.

In the summer of 2004, France was shocked by a sensational news story. A young woman, travelling with her baby on a banlieue train (RER), was attacked and mugged by a group of North African and black youth. Upon seeing the address on her identity card, the attackers deduced that she lived in a rich area, and must therefore be Jewish. From that point on, the attack took on an anti-Semitic form, with the attackers drawing swastikas on her, cutting her hair, and making marks on her face with a knife. No one on the train attempted to protect her or her baby; no one pulled the alarm.

Public outrage immediately followed the incident for the next couple of days, including many shocked remarks by politicians. The source of outrage was neither what the youth did nor the Muslim-Jewish tension, but rather the passivity of the other passengers (although "expert" writing quickly appeared in the newspapers 
analysing the behaviour of the banlieue youth). We all knew the banlieue youth does that kind of thing. We all know about the tensions between the followers of these two religions. But how to account for the conduct of the other passengers, who did not even come forward to testify? In the midst of growing reactions to the incident, no one really thought about another possibility: perhaps there was nothing to do simply because nothing happened, perhaps "because the event did not take place" (Rancière 2005b:191).

This possibility was not raised because the story fit only too well with the stereotypical image of and prejudices against the banlieues and their inhabitants. The significant point here is that it was this image of the banlieue that motivated the comments and responses of the politicians and the media rather than the facts of the story, which, at the time, had yet to be established. Two days later the young woman admitted to inventing the whole story.

This non-event, I believe, is an example that points to the effects of various sensible evidences that were put into place over decades and the workings of the standard chain of inference that puts immigrants and banlieues in the category of dangerous things. As we have seen, the construction of this chain of inference has followed from a consolidation of what I called, following Rancière, an aesthetic regime-certain framings of times and spaces. I would argue that a critical engagement with ideology starts with a questioning of the sensible evidences put in place within such a regime. Much as Lakoff's example presented at the outset of this article exposes how our everyday categorisations perhaps too easily rely on an assumption of commonality, the "Girl on the RER" episode shows how understandings of banlieues are tainted by certain framings of space.

To come back to the argument with which I started, the so-called "securitarian ideology" does not consist in the deployment of more and tougher measures and practices of repression, although these are its material manifestations. It consists in the putting in place of sensible evidences that provide the conditions of possibility for the legitimate deployment of such measures and the normalisation of such practices (such as random identity checks targeting certain groups etc). Therefore, the most perverse consequence of this ideology (this putting in place of certain sensible evidences) is not the increasing number and intensity of repressive measures, but the consolidation of an aesthetic regime, the sensible givens of which made the consensual application of such measures possible, legitimate, even necessary in order to protect the Republic from Cavafy's barbarians at the gate.

\section{Acknowledgements}

I am grateful to Vinay Gidwani, Claire Hancock, and the three referees for their constructive comments.

\section{Endnotes}

1 Following these remarks, Hortefeux was condemned for racial insult in 2010, but did not resign despite calls for him to do so. Eventually he was replaced in February 2011.

2 My page references to Susser (1996) and Laclau (1996) do not refer to the page numbers in the print version as I only have access to the HTML version of these articles. Susser does not provide the page number for the Giddens quote.

3 Many thanks to Referee 3 for suggesting this link. 
4 The distinction Althusser makes between science and ideology may be less sharp than my account suggests. See Gidwani's much more nuanced discussion in his Capital, Interrupted (2008:5-7). While recognizing its merits, however, Gidwani does not work with Althusser's notion of ideology, but prefers, instead, Foucault's notion of the "cultural". Foucault, he argues (2008:143), "provides a compelling archaeology of the cultural in The Order of Things. The 'cultural' denotes empiricities - the 'sayable' and the 'visible' - that acquire a regional, stratified form and exert a generative 'pull' on actions. Empiricites are powerfulthey constitute a cultural field-in this precise sense of affecting conduct". This interpretation, as we will see, resonates with what is proposed in this article, as Rancière was admittedly influenced by Foucault's conceptualisation.

5 There are Foucauldian links here, which I explore below, also unpacking what Rancière's term "very space" may imply.

6 This is not to suggest that the banlieues have acquired a negative image only in the 1970s; their image as a sort of "feared outside" predates this (for example, the faubourgs beyond the city walls, "the Apaches" of Belleville at the turn of the twentieth-century, or the banlieue rouge of the 1960s).

7 Begag here is referring to the 1990 revolts in this banlieue of Lyon, which were unprecedented in terms of their scale at the time. The term "casseur" is difficult to translate concisely. Le Robert \& Collins dictionary translates the term as "demonstrator who damages property", or "rioting demonstrator". It literally means "breaker".

8 This kind of delegitimisation is not exclusive to French politicians. Kipfer (2011) points to a similar trend among established Left and certain intellectuals.

9 See Barella's blog at http://lajustice.blogs.liberation.fr/

10 The communication was published before the law was finally adopted. It is available on the Ligue des droits de l'Homme Toulon section website:http://www.ldhtoulon.net/spip.php?article3362 (last accessed 15 July 2011).

11 There may be even more dubious practices. As it was documented by the newspaper Le Canard enchaîné (6 May 2009), during the demonstrations of 1 May in Paris, civil police officers (who were photographed getting off from the police buses) deliberately provoked the police officers watching the peaceful demonstrators, started a fight that brought in some of the demonstrators as well, then pointed to their colleagues who to arrest-a "more efficient way for the penal procedure", an official confirmed.

12 http://www.amnesty.fr/sites/default/files/frenchreport.pdf

13 The disruption of established ways of perceiving and making sense of things is the sublime element in Rancière's politics (Dikeç 2012).

\section{References}

Amnesty International (2009) France: des policiers au-dessus des lois. http://www.amnesty.fr/ sites/default/files/frenchreport.pdf (last accessed 15 July 2011)

Aubusson de Cavarlay B (2008) La nouvelle inflation carcérale. In L Mucchielli (ed) La frénésie sécuritaire: retour à l'ordre et nouveau contrôle social (pp 52-63). Paris: La Découverte

Autain C, Beaud S, Belaïd C, Chemetov P (eds) 2006 Banlieue, lendemains de révolte. Paris: La dispute

Barella D (2008) Sarkozy, entre réformes sécuritaires inefficaces et agitation sterile. http://lajustice.blogs.liberation.fr/barella/2008/10/nicolas-sarkozy.html (last accessed 15 July 2011)

Begag A (1990) La révolte des lascars contre l'oubli à Vaulx-en-Velin. Les Annales de la recherche urbaine 49:114-121

Bourgouin N (2008) Les chiffres du crime: statistiques criminelles et contrôle social, France 18252006. Paris: L'Harmattan

Chalom M and Léonard L (2003) Insécurité, police de proximité et gouvernance locale. Paris: L'Harmattan

Commission Nationale de Déontologie de la Sécurité (2009) Commission Nationale de Déontologie de la Sécurité Rapport. http://www.cnds.fr/avis/RA_2009_complet.pdf (last accessed 15 July 2011) 
Danet J (2008) Cinq ans de frénésie pénale. In L Mucchielli (ed) La frénésie sécuritaire: retour à l'ordre et nouveau contrôle social (pp 19-29). Paris: La Découverte

Data L (2009) Le grand truquage: comment le gouvernement manipule les statistiques. Paris: La Découverte

Déotte J-L (2004) The differences between Rancière's Mésentente (political disagreement) and Lyotard's Différend. SubStance 33(1):77-90

Dikeç M (2007) Badlands of the Republic: Space, Politics and Urban Policy. Oxford: Blackwell

Dikeç M (2012) Politics is sublime. Environment and Planning D: Society and Space 30(2): 262-279

Eagleton T (1991) Ideology: An Introduction. London: Verso

Ferguson K (2007) The Politics of Judgement: Aesthetics, Identity, and Political Theory. Lanham: Lexington

Ferret J and Mouhanna C (eds) (2005) Peurs sur les villes: vers un populisme punitif à la française? Paris: Presses universitaires de France

Frow J (1994) Marxism and literary history. In T Eagleton (ed) Ideology (pp 295-302). London: Longman

Gidwani V (2008) Capital, Interrupted: Agrarian Development and the Politics of Work in India. Minneapolis: University of Minnesota Press

Jean J-P (2010) Les réformes pénales 2000-2010: entre inflation législative et révolutions silencieuses. Regards sur l'actualité 357:8-22

Kant I (1998 [1781]) Critique of Pure Reason (trans and ed P Guyer and A W Wood). Cambridge: Cambridge University Press

Kipfer S (2011) Decolonization in the heart of empire: Some Fanonian echoes in France today. Antipode 43(4): 1155-1180

Laclau E (1996) The death and resurrection of the theory of ideology. Journal of Political Ideologies 1(3):201-220

Laclau E and Mouffe C (1985) Hegemony and Socialist Strategy: Towards a Radical Democratic Politics. London: Verso

Lakoff G (1987) Women, Fire, and Dangerous Things: What Categories Reveal About the Mind. Chicago: University of Chicago Press

Le Canard enchaîné (2003) Comment la police d'en bas mitonne les statistiques d'en haut. 23 April

Le Canard enchaîné (2009) Ces policiers qui "chauffent" les manifs. 6 May

Les dossiers du Canard (2009) Je te vois! October

Le Monde (2002) Jean-Louis Borloo esquisse son plan pour une "nouvelle bataille de France". 28 May

Le Monde (2002) Le ministre veut publier plus fréquemment les chiffres de la délinquance. 31 May

Le Monde (2010) Pour une vrai réforme de la garde à vue! 12 March

Libération (2002) Les Français ont-ils peur de tout? 8 April

Libération (2003) Des quotas de gardes à vue dans les commissariats de l'Hérault. 31 October

Libération (2009) Sécurité: leurres du bilan. 22 April

Libération (2010) Sarkozy braque la police. 5 January

Libération (2010) Pour les cinq de Villiers-le-Bel. 21 June

Libération (2011) Non-lieu pour les deux policiers de l'affaire de Clichy-sous-Bois. 27 April

Matelly J-H and Mouhanna C (2007) Police: des chiffres et des doutes. Paris: Michalon

Milburn P (2008) De la frénésie de sécurité à la surpénalisation: la justice sous pression. In

L Mucchielli (ed) La frénésie sécuritaire: retour à l'ordre et nouveau contrôle social (pp 41-51).

Paris: La Découverte

Mucchielli L (2008a) Introduction. In L Mucchielli (ed) La frénésie sécuritaire: retour à I'ordre et nouveau contrôle social (pp 5-17). Paris: La Découverte

Mucchielli L (2008b) Faire du chiffre: le nouveau management de la sécurité. In L Mucchielli (ed) La frénésie sécuritaire: retour à l'ordre et nouveau contrôle social (pp 99-112). Paris: La Découverte

Panagia D (2006) The Poetics of Political Thinking. Durham: Duke University Press

Rajsfus M (2002) La police et la peine de mort: 1977-2001 = 196 morts. Paris: L'Esprit frappeur 
Rancière J (1994) On the theory of ideology: Althusser's politics. In T Eagleton (ed) Ideology (pp 141-161). New York: Pearson

Rancière J (2000a) Dissenting words: a conversation with Jacques Rancière. diacritics 30(2):113-126

Rancière J (2000b) What aesthetics can mean. In P Osborne (ed) From an Aesthetic Point of View: Philosophy, Art and the Senses (pp 13-33). London: Serpent's Tail

Rancière J (2000c) Le partage du sensible: Esthétique et politique. Paris: La Fabrique

Rancière J (2000d) Jacques Rancière: Literature, politics, aesthetics (interviewed by S Guénoun and J H Kavanagh). SubStance 29(2):3-24

Rancière J (2003) "The thinking of dissensus: Politics and aesthetics." Paper presented at the Fidelity to the Disagreement: Jacques Rancière and the Political conference, Goldsmiths College, London, 16-17 September

Rancière J (2005a) From politics to aesthetics? Paragraph 28(1):13-25

Rancière J (2005b) Chroniques des temps consensuels. Paris: Seuil

Rancière J (2007) Les territoires de la pensée partagée (interviewed by J Lévy, J Rennes and D Zerbib). http://espacestemps.net/document2142.html (last accessed 15 December 2011)

Rancière J (2009) Politique de l'indétermination esthétique. In J Game and A W Lasowski (eds) Jacques Rancière et la politique de l'esthétique (pp 157-175). Paris: Éditions des archives contemporaines

Rigouste M (2009) L'ennemi intérieur: la généalogie coloniale et militaire de l'ordre sécuritaire dans la France contemporaine. Paris: La Découverte

Salas D (2008) La volonté de punir: essai sur le populisme penal. Paris: Hachette

Sarkozy N (2003) Déclaration de M. Nicolas Sarkozy, ministre de l'intérieur, de la sécurité intérieure et des libertés locales, sur les grandes orientations du budget du ministère pour 2004, la politique de sécurité intérieure, la sécurité civile, la politique de maîtrise de l'immigration et la réforme du ministère et de son administration territorial. Réunion des préfets à Paris, 26 September

Schaeffer J (2004) Sensus Communis. In W Jost and W Olmsted (eds) Rhetoric and Rhetorical Criticism (pp 278-293). Oxford: Blackwell

Susser B (1996) The domains of ideological discourse. Journal of Political Ideologies 1(2):165181

Tévanian P (2003) Le ministère de la peur: réflexions sur le nouvel ordre sécuritaire. Paris: L'Esprit frappeur

Žižek S (1994) The spectre of ideology. In S Žižek (ed) Mapping Ideology (pp 1-33). London: Verso 